\title{
GSK3 $\beta$ Overexpression Induces Neuronal Death and a Depletion of the Neurogenic Niches in the Dentate Gyrus
}

\author{
MaSalomé Sirerol-Piquer, ${ }^{1,2}$ Pilar Gomez-Ramos, ${ }^{3}$ Félix Hernández, ${ }^{4}$ Mar Perez, ${ }^{3}$ \\ María A. Morán, ${ }^{3}$ Almudena Fuster-Matanzo, ${ }^{4}$ José J. Lucas, ${ }^{4,5}$ Jesús Avila, ${ }^{4,5 *}$ \\ and Jose Manuel García-Verdugo ${ }^{1,2,5 *}$
}

\begin{abstract}
Overexpression of GSK3 $\beta$ in transgenic mice induces learning deficits and some features associated with Alzheimer's disease (AD), including dentate gyrus (DG) atrophy. Here, we assessed whether these mice also recapitulate DG atrophy as well as impaired neurogenesis reported in $\mathrm{AD}$. Ultrastructural analysis revealed that there were fewer and more disorganized neurogenic niches in these animals, coupled with an increase in the proportion of immature neurons. Indeed, the maturation of granule cells is delayed as witnessed by the alterations to the length and patterning of their dendritic trees and to the mossy fiber terminals. Together with an increase in neuronal death, these phenomena lead to a marked decrease in the number and disorganization of granule cells of the DG. Our results suggest that GSK3 $\beta$ overexpression perturbs proliferation and maturation, resulting in the loss of immature neurons. In turn, the activation of microglia is stimulated in conjunction with a decrease in the birth of new functional neurons, leading to the deterioration of this structure. These data support the idea that by inducing degeneration of the DG, GSK3 $\beta$ could be involved in the pathogenesis of AD. $\odot 2010$ Wiley-Liss, Inc.
\end{abstract}

KEY WORDS: GSK3ß; overexpression; hippocampal stem cells; proliferation; maturation; Alzheimer's disease

Departamento de Neurobiología Comparada, Instituto Cavanilles,
Universidad de Valencia, 46980 Valencia, Spain; ${ }^{2}$ Departamento de
Morfología Celular, Centro de Investigación Príncipe Felipe, CIBERNED,
46013 Valencia, Spain; ${ }^{3}$ Departamento de Anatomía, Histología y
Neurociencia, Facultad de Medicina, Universidad Autónoma de Madrid,
28029 Madrid, Spain; ${ }^{4}$ Departamento de Neurociencia, Centro de Biol-
ogía Molecular "Severo Ochoa," CSIC/UAM, Universidad Autónoma de
Madrid, 28049 Madrid, Spain; ${ }^{5}$ Centro de Enfermedades Neurodegener-
ativas (CIBERNED), 28031 Madrid, Spain Additional Supporting Information may be found in the online version of this article.

Grant sponsor: Ministerio de Ciencia e Innovación, Spanish Plan Nacional; Grant numbers: SAF2008-01274, SAF-2006-02424; Grant sponsor: CIBERNED; Grant number: CD06/05/113/; Grant sponsor: Instituto de Salud Carlos III, Red de Terapia Celular (TERCEL); Grant number: RD06/ 0010/0022; Grant sponsor: Universidad Autónoma de Madrid; Grant number: CCG08-UAM-SAL-4207; Grant sponsors: Fundación Marcelino Botín, Fundación Ramón Areces, Comunidad Autónoma de Madrid.

*Correspondence to: Jesús Avila, Departamento de Neurociencia, Centro de Biología Molecular "Severo Ochoa," CSIC/UAM, Universidad Autónoma de Madrid, C/Nicolás Cabrera 1, 28049 Madrid, Spain. E-mail: javila@cbm.uam.es or Jose Manuel García-Verdugo, Departamento de Neurobiología Comparada, Instituto Cavanilles, Universidad de Valencia, 46980 Valencia, Spain. E-mail: j.manuel.garcia@uv.es

Accepted for publication 16 March 2010

DOI 10.1002/hipo.20805

Published online 23 June 2010 in Wiley Online Library (wileyonlinelibrary.com).

\section{INTRODUCTION}

In adult mammals, neurogenesis occurs principally in two brain regions: the subventricular zone and the subgranular zone (SGZ) of the hippocampus. In both these domains, the stem cells that exist are a subset of astrocytes (Doetsch and Hen, 2005). In the SGZ, astrocytes (Type B cells) divide to generate intermediate precursors (Type D cells), which remain in clusters of two to four cells in neurogenic niches that are formed by the processes of astrocytes (Seri et al., 2004). Type D cells progressively generate more differentiated progeny, which eventually mature into granule neurons. Ultrastructurally, astrocytes/Type B cells have a light cytoplasm that contains a few ribosomes and intermediate filaments, and their irregularly shaped contours intercalate between neighboring cells. Type D cells are found adjacent to Type B cells at the base of the granular cell layer (GCL), and they have smooth contours as well as a darker nuclei and dark scant cytoplasm containing many ribosomes. The newly differentiated granule cells that are produced grow dendrites into the molecular layer, and they send axons into the CA3 region. Although the precise physiological functions of neurogenesis as well as the full spectrum of functional implications in adult brain are still under intense investigation, it becomes apparent that new neurons that integrate in the hippocampus play important roles in aspects of learning and memory.

The magnitude of the neurogenesis declines with age, raising the possibility that reduced neurogenesis may account, to some degree, for the impaired learning and memory and cognitive deterioration in the elderly (Seki and Arai, 1995; Kuhn et al., 1996; Tropepe et al., 1997; Kempermann et al., 1998, 2002). Adult neurogenesis in the dentate gyrus (DG) could be responsible for encoding new memories (Aimone et al., 2006). In humans, this DG neurogenesis has been related to learning and short-memory acquisition (Zhao et al., 2008).

Alzheimer's disease (AD) is characterized by a progressive memory loss and cognitive decline with DG degeneration, which could be due, in part, to impaired DG neurogenesis. There has therefore been an increasing level of interest in understanding 
whether the process of neurogenesis is altered in the disease and thus contributes to cognitive impairment (Chuang,; Jin et al., 2001; Jin et al., 2004; Li et al., 2008; Lazarov and Marr, 2009).

In familial $\mathrm{AD}(\mathrm{FAD})$, mutations in three genes encoding the APP, PS-1, and PS-2 proteins promote the onset of the disease (Price and Sisodia, 1998), which is associated with an increase in GSK3 $\beta$ activity (Baki et al., 2004; Avila, 2006; Kimura et al., 2007; Townsend et al., 2007). In sporadic AD, GSK3 $\beta$ overactivation may also occur, because a recently identified LRP6 genetic variation has been associated with late onset $\mathrm{AD}$, resulting in a decrease in Wnt signaling and an increase in GSK3 $\beta$ activity (De Ferrari et al., 2007). Also, GSK3 $\beta$ has been associated with the risk of AD (Schaffer et al., 2008).

We have studied the effect of GSK3 $\beta$ overexpression in DG neurogenesis in a conditional transgenic GSK3 $\beta$ mouse (Lucas et al., 2001). We found that GSK3 $\beta$ overexpression reduces proliferation and impairs maturation, making the neurogenesis in the DG unproductive, as these cells do not develop into fully mature, functional neurons. As a consequence, it appears that the decrease in the volume of DG is due to the depletion of neuronal progenitor cells and neurons.

\section{MATERIALS AND METHODS}

\section{Animals, BrdU Injections, and Tissue Processing}

\section{Animal care}

Tet/GSK3 $\beta$ mice were generated as described previously (Lucas et al., 2001). Briefly, Tet/GSK3 $\beta$ mice were bred by crossing TetO mice (carrying the bidirectional Tet-responsive promoter followed by the GSK3 $\beta$ and $\beta$-galactosidase cDNAs, one in each direction) with CamKII $\alpha$-tTA mice. The dual transgenic mice were designated Tet/GSK3 $\beta$, and they overexpress GSK3 $\beta$ in the cortex and hippocampus. Transgenic mice as well as wt mice (C57BL/6) were bred at the Centro de Biologia Molecular "Severo Ochoa" (Madrid, Spain), and the mice were kept on a normal light-dark cycle (12-h light-dark), with free access to food and water.

\section{BrdU injections}

Transgenic or wt mice (1 or 3 months old) received four consecutive intraperitoneal injections of $\mathrm{BrdU}(100 \mathrm{mg} / \mathrm{kg})$ at a 2-h interval, and $2 \mathrm{~h}$ after the last injection, the animals were sacrificed by intracardial perfusion.

\section{Tissue processing}

Animals were anesthetized and perfused intracardially with $0.9 \%$ saline followed $4 \%$ paraformaldehyde (PFA). The brain was removed, postfixed overnight in $4 \% \mathrm{PFA}$, and $40-\mu \mathrm{m}$ coronal or $30-\mu \mathrm{m}$ sagittal sections were obtained on a vibratome.

For electron microscopy (EM), animals were perfused with $0.9 \%$ saline followed by $2 \%$ PFA and $2.5 \%$ glutaraldehyde.
Their brains were removed and postfixed overnight in the same fixative, and $200-\mu \mathrm{m}$ coronal sections were obtained and processed for EM (see below). All animal care was carried out in accordance with institutional guidelines.

\section{Immunohistochemistry}

For BrdU immunostaining, sections were incubated in $2 \mathrm{~N}$ $\mathrm{HCl}\left(30 \mathrm{~min}\right.$ at $\left.37^{\circ} \mathrm{C}\right)$ and then rinsed for $15 \mathrm{~min}$ in $0.1 \mathrm{M}$ borate buffer $(\mathrm{pH}$ 8.5). For BrdU, doublecortin, IbaI, and MAP2 immunohistochemistry, the sections were rinsed in PBS and incubated in blocking solution, followed by an overnight incubation at $4^{\circ} \mathrm{C}$ with the primary antibody: mouse antiBrdU, 1:150 (DakoCytomation); mouse anti-DCX 1:400 (Santa Cruz Biotechnology); rabbit anti-Iba-1 1:200 (Wako); or rabbit anti-MAP2, 1:250 (Sigma). The sections were then washed and incubated for $1 \mathrm{~h}$ with a goat antimouse biotinylated antibody (1:400, Vector) and then for 90 min with an avidin-biotin-peroxidase complex (ABC, 1:250, Vector). The antibody staining was finally visualized with diaminobenzidine (DAB, $0.05 \%$, Sigma), and the sections were counterstained with cresyl violet.

For immunofluorescence, immunostaining was carried out following a standard procedure. The sections were first blocked for $1 \mathrm{~h}$ and then incubated overnight at $4{ }^{\circ} \mathrm{C}$ with the primary antibodies: mouse anti- $\beta$-gal, 1:200 (Promega); mouse antiGFAP, 1:400 (PharMingen); rabbit anti-DCX, 1:150 (Abcam); chicken anti-TUJ1, 1:500 (Chemicon); mouse anti-Nestin, 1:150 (Sigma); mouse anti-PSA-NCAM, 1:200 (AbCys). After washing with $\mathrm{PBS}$, the primary antibodies were detected with the appropriate mouse, rabbit, or chicken Alexa-Fluor-488/647 secondary antibody (Invitrogen), and the sections were examined by confocal laser microscopy.

\section{Cell Counting}

The quantification of the cells that took up BrdU was performed in five mice in each group of 1 and 3-month-old mice. Two series of systematically selected brain sections $(200 \mu \mathrm{m}$, every sixth section, and five to six sections in each series) were studied in each animal. Only $\mathrm{BrdU}^{+}$cells located in the SGZ were counted using a $100 \times$ oil immersion lens. The Student's $t$-test for pairwise comparison was used for the statistical analysis, and value of $P<0.001$ was considered significant for 1 -month-old mice and $P<0.005$ for 3-month-old mice. The $\mathrm{BrdU}^{+}$cell counts were plotted as percentages. To validate the quantification data, a CAST stereological system was applied to the same series of sections as those counted previously in two animals from each group.

The number of $\mathrm{BrdU}^{+}$cells in the foci was counted in the SGZ. The foci were classified by categories according to the number of $\mathrm{BrdU}^{+}$cells present, and they were considered as category 1 or 2 when they contained one or two $\mathrm{BrdU}^{+}$cells, respectively. A chi-square nonparametric statistical analysis $(P<0.005)$ and correlation analysis were carried out. 


\section{Timm Staining}

The tissue was processed for Timm staining as described previously (Wenzel et al., 1997), whereby the sections were placed in a desiccation chamber with a beaker with $100 \mathrm{ml}$ of a $0.1 \%$ $\mathrm{Na}_{2} \mathrm{~S}$ ( $\mathrm{pH}$ 7.3). After $24 \mathrm{~h}$, the sections were rinsed in $95 \%$ $\mathrm{EtOH}$, followed by $70 \%$ and $50 \% \mathrm{EtOH}$, and finally water. Subsequently, the sections were placed in the developer solution for $3 \mathrm{~h}$ and then rinsed in running tap water for $10 \mathrm{~min}$, and finally they were placed in a 5\% sodium thiosulphate solution and rinsed with water.

\section{Tissue Processing for Semithin Sections and EM}

Coronal sections $(200 \mu \mathrm{m})$, corresponding to the same hippocampal region, were postfixed in $2 \%$ osmium tetroxide $\left(\mathrm{OsO}_{4}\right)$ for $2 \mathrm{~h}$, rinsed, dehydrated, and embedded in Durcupan (Durcupan, Fluka). To study the overall organization of the DG, the number of niches, and microglia, serial semithin sections $(1.5 \mu \mathrm{m})$ were cut with a diamond knife and stained with $1 \%$ toluidine blue. Subsequently, the area of interest was trimmed, and ultrathin sections $(0.06 \mu \mathrm{m})$ were obtained from this material with a diamond knife, which was stained with lead citrate and examined under a Fei Tecnai Spirit electron microscope.

Microglia and niches quantification were carried out on 15 serial semithin sections per mouse and on three mice per group. The same slides were used to quantify both microglia and niches. Data are reported as the means $( \pm S D)$ of the number of microglia or niches per millimeter square in the DG. The Student's $t$-test was used for pairwise comparison, and $P<$ 0.005 was considered significant. In some experiments, the optical dissector was used for the analysis, and similar results were obtained.

\section{RESULTS}

\section{DG Neurodegeneration with the Aging of Tet/GSK3 $\beta$ Mice}

Overexpression of GSK3 $\beta$ in vivo produces neuronal cell death as well as increasing the number of reactive microglia in the DG of 3-month-old mice (Lucas et al., 2001). To characterize this neurodegeneration, we analyzed thionine staining in brain sections from 2-year-old Tet/GSK3 $\beta$ mice. The images showed a clear reduction in the size of the DG, which is almost completely lost in Tet/GSK3 $\beta$ mice when compared with the wt mice (Figs. 1A,B). At 3 months of age, a smaller reduction in thickness was observed in the GCL in Tet/GSK3 $\beta$ mice (Figs. 1C,D) and, thus, there appears to be a progressive shrinking of the DG with age (Fig. 1). Similar differences were found when the Tet/GSK3 $\beta$ mice were compared to Tet O/GSK3 $\beta$ mice rather than the wt mice (see Lucas et al., 2001 and Supporting Information Fig. 1).

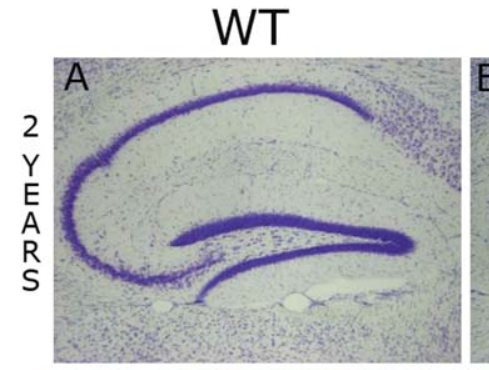

Tet/GSK-3 $\beta$
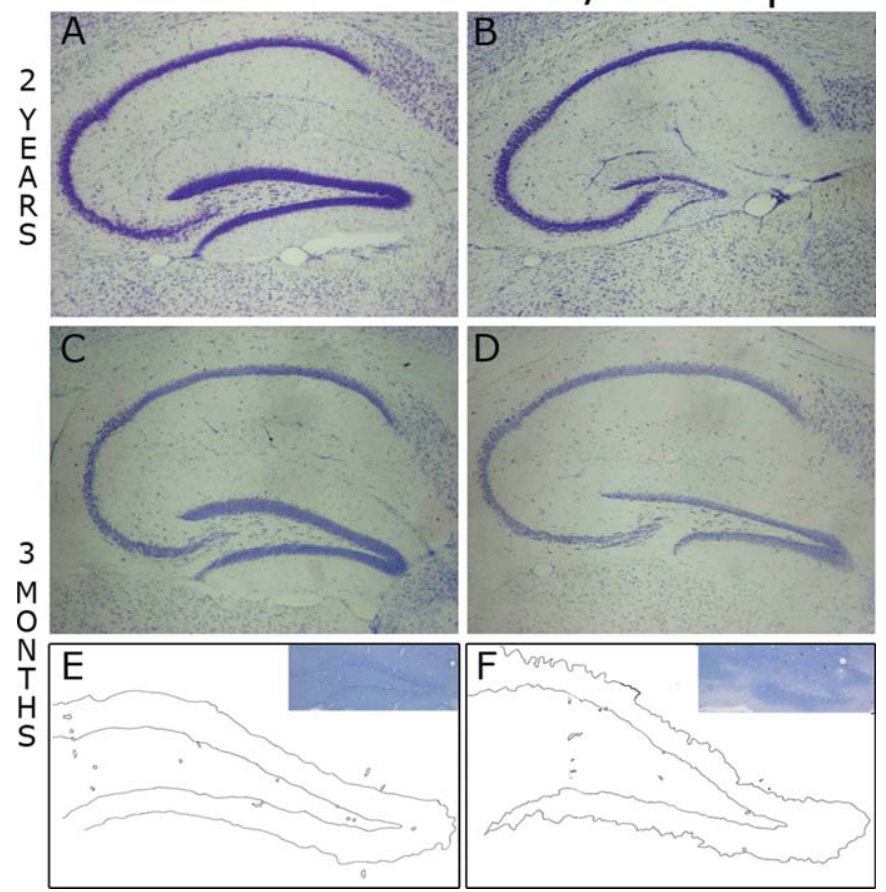

FIGURE 1. DG atrophy in Tet/GSK3 $\beta$ mice. Thionine-stained sagittal sections from 2-year-old wt (A) and Tet/GSK3 $\beta$ (B) mice as well as sections from 3-month-old wt (C) and Tet/GSK3 $\beta$ (D) mice. DG brightfield microscopy camera lucida images from 3month-old wt (E) and Tet/GSK3及 (F) mice. The pictures corresponding to the drawn sections are depicted in the upper part of the image. Pictures were obtained from the same level. [Color figure can be viewed in the online issue, which is available at wileyonlinelibrary.com.]

To study the morphological changes to the DG in further detail, 1.5- $\mu \mathrm{m}$ toluidine-stained sections from 3-month-old Tet/ GSK3 $\beta$ and wt mice were analyzed by brightfield microscopy. The camera lucida images obtained showed a clear reduction in thickness of the GCL, as well as discontinuities, not only in the SGZ where the neurogenic niches are located but more clearly in the supragranular zone that is composed of differentiated granule neurons (Figs. 1E,H). These results suggest that the new cells generated were poorly organized and that the activity of the niche had been dampened. Furthermore, these changes were accompanied by the presence of abundant microglia (see below).

\section{DG Disorganization and Impoverished Survival of the Neurogenic Niches in Tet/GSK3 $\beta$ Mice}

The degeneration in the DG could be the result of increased neuron death and/or diminished neurogenesis. To further analyze the progressive atrophy of the DG, we studied the organization of the GCL in toluidine-blue semithin sections. Although the characteristic columnar organization of the GCL was evident in a panoramic view of the wt DG (Fig. 2A), the DG of Tet/GSK3 $\beta$ mice was more randomly arranged (Fig. 2B). Moreover, instead of presenting the homogeneous profile observed at the wt sections, the supragranular zone was 

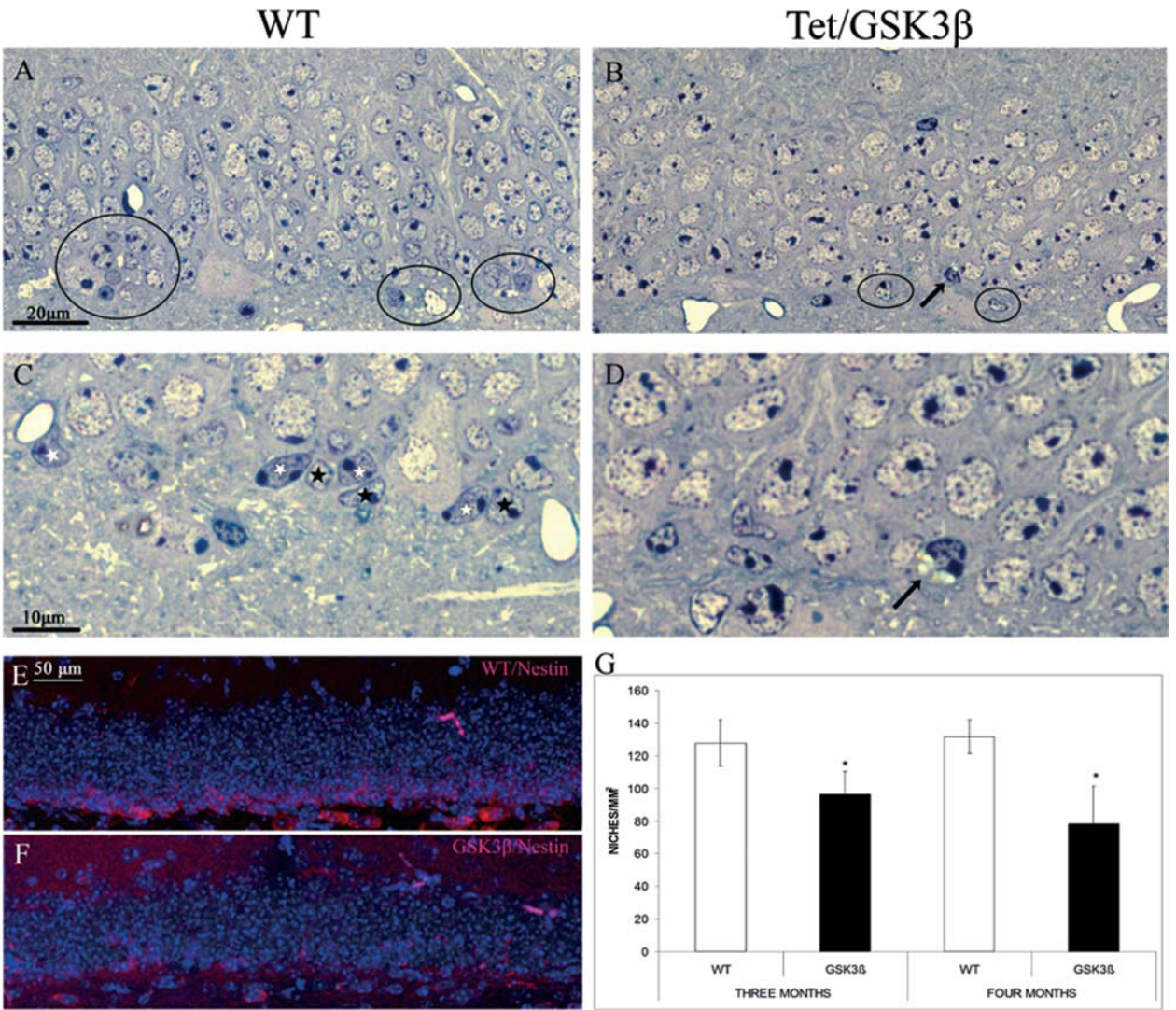

FIGURE 2. Cellular disorganization and impaired development of neurogenic niches in the DG of Tet/GSK3 $\beta$ mice. A, B: Semithin sections stained with toluidine blue showing a panoramic view of the DG. In wt (A), the typical columnar organization is observed, whereas in Tet/GSK3 $\beta$ mice (B), a more mosaic organization of the cells is evident. Microglia are indicated by arrows and the niches containing type $\mathrm{B}$ and/or type $\mathrm{D}$ cells are enclosed by circles. C, D: Detail of the niches in the SGZ, with astrocytes/stem cells (black

more irregular and its thickness diminished (Figs. 2A,B). As described previously, the soma of astrocytes or type B $\left(\mathrm{GFAP}^{+}\right)$ cells lies in the SGZ, and these cells extend a single or dual apical process radially across the GCL (Encinas et al., 2006). However, this organization was not evident in Tet/GSK3 $\beta$ mice, and astrocytosis was observed ((Lucas et al., 2001) and Supporting Information Fig. 1). We found that astrocytes were displaced laterally, occupying the empty spaces that appeared after neurodegeneration (Supporting Information Fig. 2). These results suggest that proliferation, migration, and/or differentiation of precursor cells might be affected in Tet/GSK3 $\beta$ mice.

To study how proliferation was affected, the neurogenic niches in the DG were analyzed. In wt sections, the neurogenic niches could be clearly discerned due to their morphology, the number of cells, and their composition. By contrast, in the Tet/ GSK3 $\beta$ sections, there was an important reduction in the number of niches, and their composition was also affected. Thus, in wt animals, the neurogenic niches were rich in each cell type (1-2 astrocytes/Type B cells and 2-4 Type D cells), whereas, in the Tet/GSK3 $\beta$ niches, there was a reduction in the Type B cells and in particular of the Type D cells (Figs. 2C,D). asterisks) and type D cells (white asterisks). Note the difference in the number of cells and the composition of the neurogenic niches. Microglia (arrows) are located close to the niche in Tet/GSK3ß mice. Nestin immunostaining in wt (E) and Tet/GSK3 $\beta$ mice (F). There is a reduction in the number of $\mathrm{Nestin}^{+}$cells in Tet/GSK3 $\beta$ mice. Quantification of the neurogenic niches in serial semithin sections (G).

The changes in the neurogenic niche were quantified in toluidine-blue semithin sections from 3 and 4-month-old mice. The results showed a 1.3-fold reduction in the density of the neurogenic niches in GSK3 $\beta$ mice when compared with wt mice, which progressed to a 1.7 -fold reduction after 4 months (Fig. 2G). These data indicate that the neurogenic niches diminish in size and number over time. These data were confirmed by examining the immunostaining for Nestin, which demonstrated the loss of neural progenitor cells in the transgenic mice: astrocytes (type B or stem cells) and more immature but still proliferating type D cells (Figs. 2E,F).

\section{Cell Proliferation in the SGZ}

To further study cell proliferation in the SGZ, BrdU incorporation into dividing cells was assessed after its intraperitoneal injection into 1 and 3-month-old wt and Tet/ GSK3 $\beta$ mice. There was less BrdU incorporation in $40-\mu \mathrm{m}$ sections from Tet/GSK3 $\beta$ mice than from wt mice (Fig. 3A). Indeed, when quantified, there was a significant decrease in the number of $\mathrm{BrdU}^{+}$cells in 1 and 3-month- 

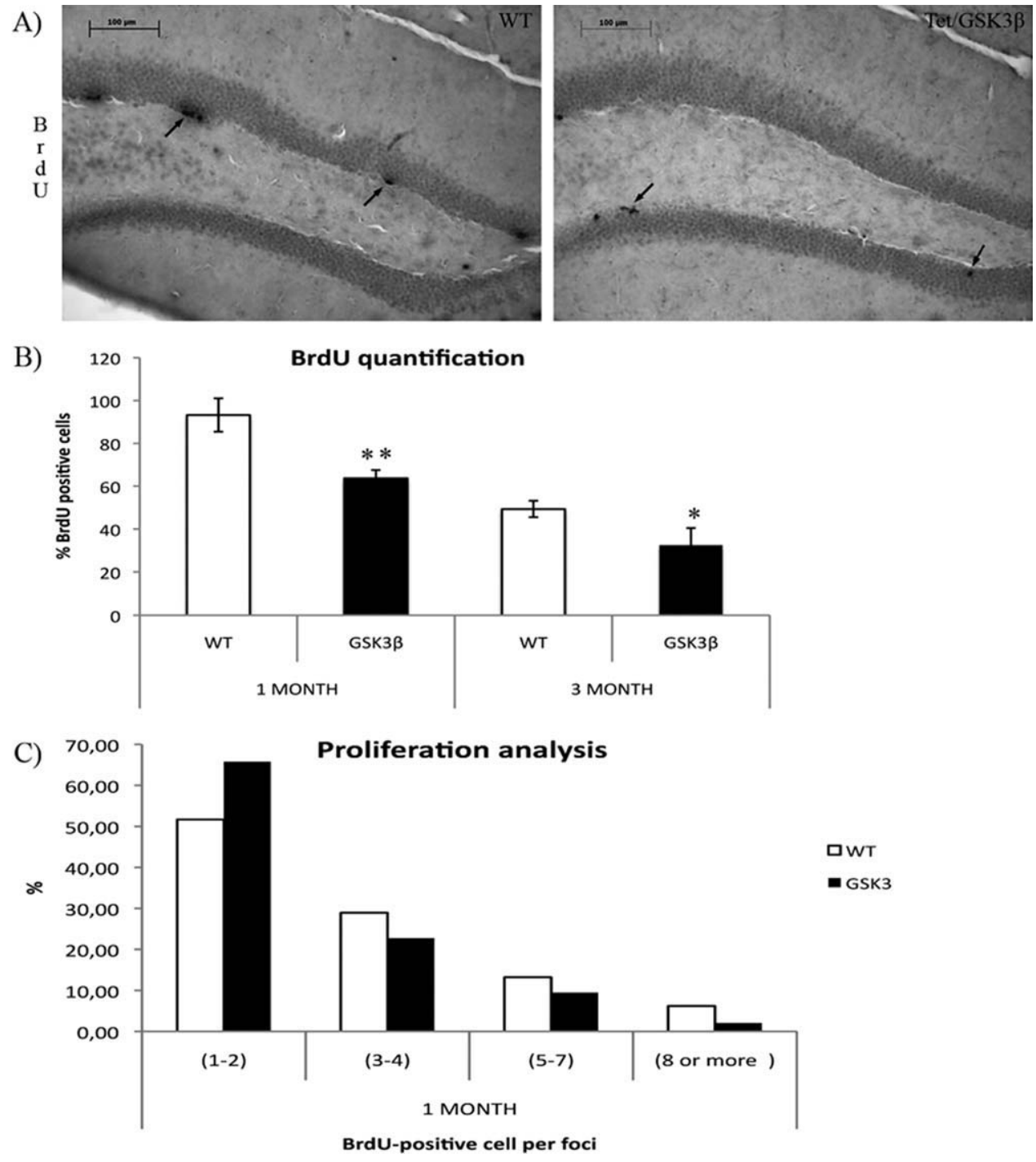

FIGURE 3. Proliferative characteristics in the SGZ of the DG. BrdU immunostaining in $w t$ and Tet/GSK3 $\beta$ mice. $\mathrm{BrdU}^{+}$cells are indicated by arrows (A). Proportions of $\mathrm{BrdU}^{+}$cells in 1 and 3month-old wt and Tet/GSK3 $\beta$ mice $\left(n=5\right.$ per group) ${ }^{* *} P<$ 0.001 and ${ }^{*} P<0.005$ (B). Quantification of the foci (proliferative neurogenic niches) based on the number of $\mathrm{BrdU}^{+}$cells as an

old Tet/GSK3 $\beta$ mice when compared with wt mice (Fig. $3 \mathrm{~B})$, in accordance with the reduction in the number of neurogenic niches. A more precise cell quantification through a stereological analysis with an optical dissector method confirmed that there were fewer $\mathrm{BrdU}^{+}$cells in GSK3 $\beta$ mice, indicating that wt mice had 1.4-fold and 1.6-fold more cells that incorporated BrdU at 1 and 3 months of age, respectively (Supporting Information Fig. 3).

Taking into account the quantitative and immunohistochemical data, as well as the morphological observations, the reduction in cell proliferation appears to be due to a loss of neural progenitor cells. Indeed, the pattern BrdU staining supports this hypothesis, because many of the multiple foci of proliferating cells in wt mice contain several $\mathrm{BrdU}^{+}$cells (neural progen- approximation of their proliferative capacity (C). Category 1-2 means one or two $\mathrm{Brdu}^{+}$cells in the foci, and so on. A chi-square test (including the Pearson chi-squared value and the linear-by-linear correlation factor) showed that the differences between wt and Tet/GSK3 $\beta$ mice are statistically significant.

itors such as astrocytes and more immature type D cells), whereas, in Tet/GSK3 $\beta$ mice, there was a reduction not only in the number of foci, but also in the number of labeled cells in each niche. To confirm these observations, the number of BrdU labeled cells per foci were quantified (Fig. 3C) in 1month-old mice that have more niches. The neuroprecursor cells behaved distinctly in Tet/GSK3b and wt mice, While wt mice tended to present niches containing more than three $\mathrm{BrdU}^{+}$cells, Tet/GSK3b mice tended to present less $\mathrm{BrdU}^{+}$ cells per niche. So there is a tendency to present more neuroprecursor cells per niche in wt mice, which correlates with the tendency of Tet/GSK3b mice to present less neuroprecursor cells per niche as indicated by the linear-by-linear correlation factor $p<0.005$ (Fig. 3C). 

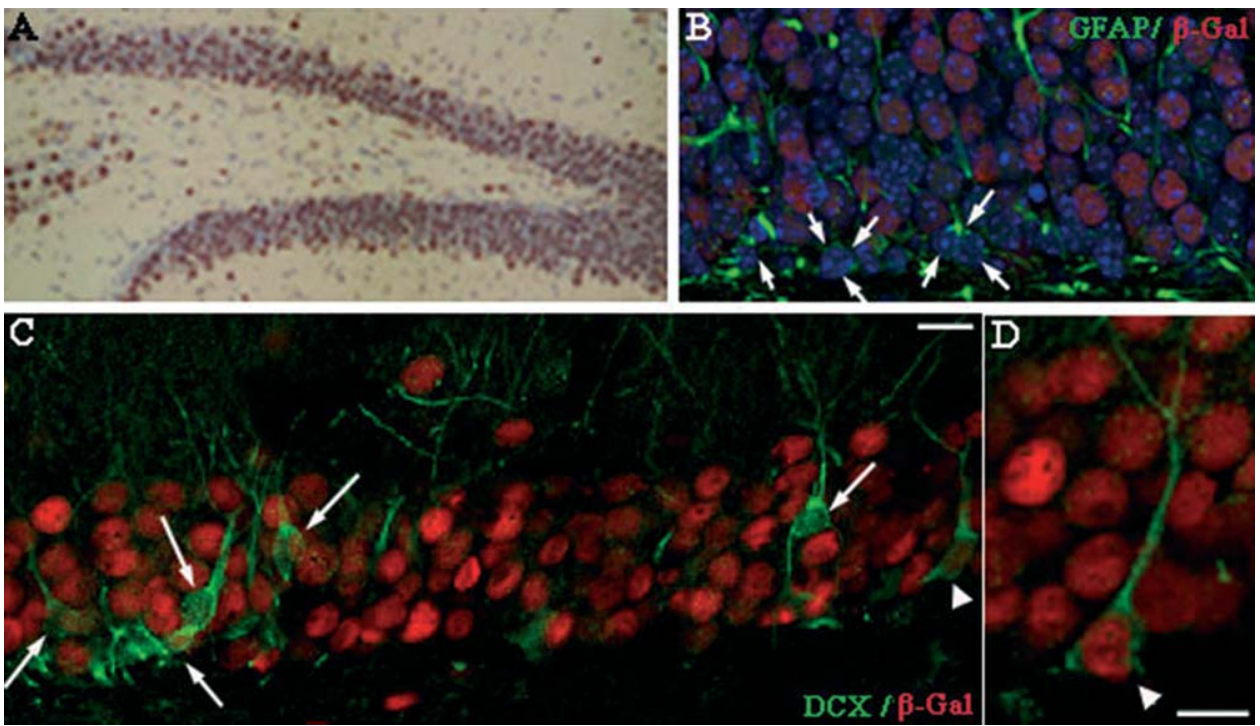

FIGURE 4. $\beta$-Galactosidase expressing cells in the DG. A: $\beta$ Galactosidase immunohistochemistry in 3-month-old Tet/GSK3 $\beta$ mice showing the abundance of $\beta$-galactosidase expressing cells along the GCL. B: Double-immunolabeling for GFAP (green) and $\beta$-galactosidase (red). Detail of the SGZ, where the staining seems less evident than in other areas. Most, if not all, $\mathrm{GFAP}^{+}$cells do not express $\beta$-galactosidase and, thus, astrocytes probably do not overexpress GSK3ß. White arrows indicate astrocytes. C, D: Hippocampal sections double-labeled with antidoublecortin (green) and anti- $\beta$-gal (red). C: Panoramic view of the DG showing that most cells are only $\mathrm{DCX}^{+}$(white arrows) and only one of them is double labeled (arrowhead: scale bar $=30 \mu \mathrm{m})$. D: Magnification of a double-labeled cell (Scale bar $=20 \mu \mathrm{m})$.

\section{Neuronal Maturation at DG in Tet/GSK3 $\beta$ Mice}

The disorganization of the GCL could reflect the failure of the newborn cells to mature and migrate. Interestingly, many cells present in different layers of the DG expressed $\beta$-gal, a marker of the GSK3 $\beta$ transgene (Figs. 4A,B). To study which cell types overexpressed $\beta$-gal, the colocalization of GFAP (a marker of astrocytes) or doublecortin (DCX, a marker of immature neurons) with $\beta$-gal was assessed. Although astrocytes did not overexpress GSK3 $\beta$ (Fig. 4B), the proliferation data suggested that neural progenitor cells derived from astrocytes should express GSK3 $\beta$. However, most of the cells expressing DCX were $\beta$-gal negative, although a few of them were labeled for both markers (Figs. 4C,D). These results indicated that not only mature granular neurons but also, newborn cells at different stages of maturation overexpress GSK3 $\beta$.

The length and pattern of the dendritic arborization is thought to be correlated with the degree of granule cell maturation (Seri et al., 2004; Zhao et al., 2006). In wt mice, the majority of the $\mathrm{DCX}^{+}$cells were uniformly oriented, aligned with the SGZ to form a layer one or two cell thick. Moreover, their apical dendrites bifurcated within the outer half of the GCL, further branching within the inner portion of the molecular layer. By contrast, in GSK3 $\beta$ transgenic mice, the $\mathrm{DCX}^{+}$cell layer was thicker (more than two cells thick), and immature neurons were frequently observed outside the SGZ immersed in the GCL. These immature neurons were morphologically more heterogeneous due to the altered orientation of their dendrites (Fig. 5B). We commonly observed granule cells with irregularly oriented apical dendrites and modified dendritic branching, as well as cells with shorter primary dendrites that bifurcated in close proximity to the neuronal soma and that formed dendritic trees with a "bushy" appearance within the GCL. Furtheremore, the presence of type D cells in the GCL was confirmed in toluidine blue stained semithin sections and by EM. These results suggests that the maturation of newborn cells was blocked in the transgenic mice (Fig. 5B). This staining was more evident in three rather than the 1-month-old transgenic mice (Figs. 5A,B).

These optical observations were validated by quantifying the $\mathrm{DCX}^{+}$cells in 1 and 3-month-old mice (Fig. 5C), and although no differences were observed in the younger mice, in 3 -month-old mice the number of $\mathrm{DCX}^{+}$cells was greater in Tet/GSK3 $\beta$ mice. To quantify the failure in maturation, the length from the soma to the bifurcation in the primary dendrite was measured (Fig. 5D). As expected, this parameter was shorter in Tet/GSK3 $\beta$ than in wt mice, supporting the visual impression that the dendrites bifurcated closer to the soma in the Tet/GSK3 $\beta$ mice. To confirm these data, immunostaining was performed with antibodies against PSA-NCAM and TUJ1, other markers of immature neurons (Supporting Information Fig. 4). PSA-NCAM and TUJ1 staining clearly increased in the Tet/GSK3 $\beta$ mice when compared with wt mice, suggesting a block in maturation.

We analyzed maturation in wt (Figs. 6A-C) and Tet/GSK3 $\beta$ (Figs. 6B-D) mice and, as expected, 1-month-old wt mice maintained more neurogenic niches in the SGL (subgranular layer) than 3-month-old wt mice (Fig. 6A). Mature granule neurons were clearly identified by EM, and they displayed a 
A)

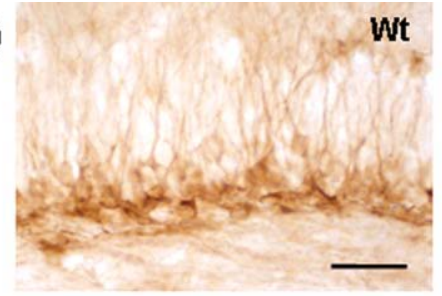

Wt

B)

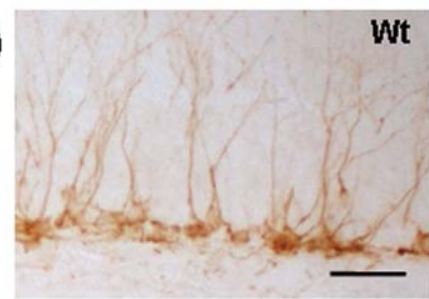

Wt

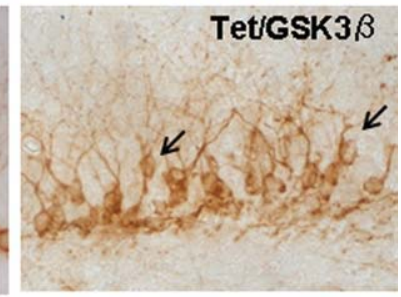

C)

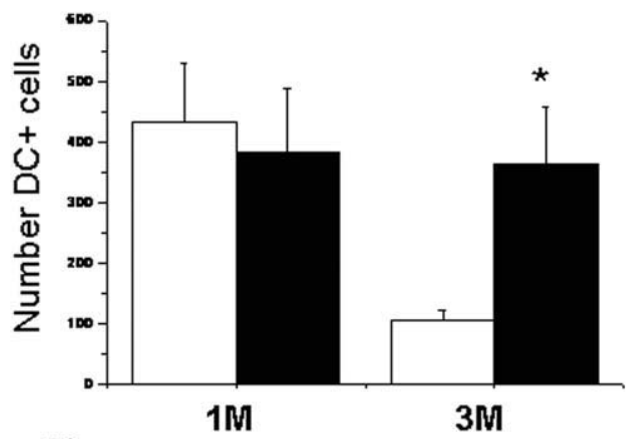

D)

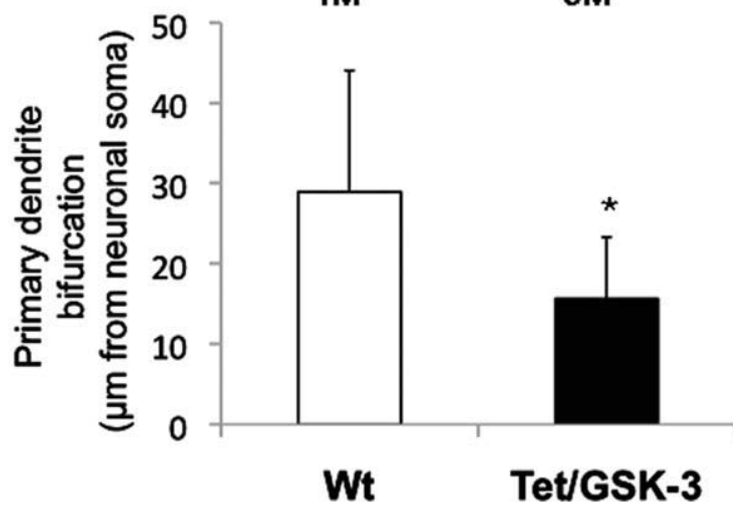

FIGURE 5. Maturation and proliferative characteristics in the SGZ of the DG. Doublecortin immunostaining of the DG from 1 (A) to 3-month-old (B) wt and Tet/GSK3 $\beta$ mice. Note the elevated number and the atypical situation of the $\mathrm{DCX}^{+}$cells in the GCL (arrows: scale bar $=100 \mu \mathrm{m}$ ). C: There are more immature neurons in 3 -month-old Tet/GSK3 $\beta$ mice $\left({ }^{*} P<0.02\right)$. D: Dendritic analysis. Confocal sections of individual $\mathrm{Dcx}^{+}$cells $(\mathrm{wt}=61$ and Tet/GSK-3 $\beta=83$ ) were reconstructed from confocal $z$ stacks. The first ramified point in close proximity to the neuronal soma of the dendritic arbor was quantified using ImageJ software with the NeuronJ plugin $\left({ }^{*} P<0.0001\right)$. [Color figure can be viewed in the online issue, which is available at wileyonlinelibrary.com.]

characteristic organization with abundant cytoplasmic organelles and clumped chromatin (Fig. 6C). By contrast, there were more immature cells in 1-month-old Tet/GSK3 $\beta$ mice than in 3-month-old Tet/GSK3 $\beta$ mice, and even more than 1-monthold wt mice (Fig. 6B). In addition, fully mature granular neurons were not observed in the GCL of the Tet/GSK3 $\beta$ mice, and most granular cells had a generally immature aspect, mainly characterized by their lax chromatin (Fig. 6D). These results again indicated that there was a block in the maturation process.

\section{Mossy Fiber Terminals}

The dendrites of newly differentiated granule cells grow into the GCL, and these cells send axons into the CA3 region. Structurally, the endings of these axons form the characteristic mossy fiber terminals (MFT) that contain numerous peripherally located mitochondria, usually associated in groups. Giant spines or excrescences from the CA3 protrude into the MFT, and they establish multiple asymmetric synaptic contacts (Amaral and Dent, 1981). Postnatal development of the mossy fiber continues for $\sim 1$ month after birth, after which these mossy fibers are on the whole fully matured. Accordingly, we further analyzed the block in maturation by studying the mossy fiber boutons of the stratum lucidum of the CA3 in 1-monthold wt and Tet/GSK3 $\beta$ mice by EM.

Mature mossy fibers appeared as large complex expansions in 1-month-old wt mice, indented by several dendritic spines that formed multiple synapses, and they were characterized by the presence of small clear vesicle clusters confined to restricted areas of the boutons (Fig. 6E). In Tet/GSK3 $\beta$ mice, the terminals were sparsely packed and rounded, with smooth contours. Only a few spines protruded into the MFTs that were completely filled with vesicles rather than presenting clusters of vesicles close to the synaptic active zones (Fig. 6F).

Timm staining selectively labels the synaptic terminals of mossy fibers due to their high- $\mathrm{Zn}^{2+}$ content, providing a tool to examine the development of mossy fibers (Danscher et al., 1976; Amaral and Dent, 1981). The pattern of Timm staining differed in 1-month-old wt and Tet/GSK3 $\beta$ mice, because there was a decrease in both the area stained and the intensity in Tet/GSK3 $\beta$ mice (Supporting Information Fig. 5). Moreover, Timm staining totally disappeared in older mice (Engel et al., 2008), suggesting that mossy fibers failed to mature.

\section{Neuronal Migration in DG of Tet/GSK3 $\beta$ Mice}

The maturation of newborn cells requires dendrite and axon morphogenesis and migration toward the GCL. These are highly dynamic processes that involve the microtubular cytoskeleton. Overexpression of the GSK3 $\beta$ protein is known to affect the microtubular organization, which, in turn, could affect the maturation, organization, and composition of the neurogenic niches as well as the reported alterations to the mossy fibers.

Microtubule organization was analyzed in 1 and 3-monthold mice, and parallel microtubule arrays were observed in the apical dendrites of granular neurons in wt mice (Figs. 7A-C). By contrast, microtubules were highly distorted and disorganized in the dendrites of Tet/GSK3 $\beta$ mice (Figs. 7B-D), which may reflect the modifications to microtubule proteins. Indeed, it was previously shown that the tau protein is hyperphosphorylated in Tet/GSK3 mice (Lucas et al., 2001). We also analyzed a microtubule protein mainly present in dendrites, 

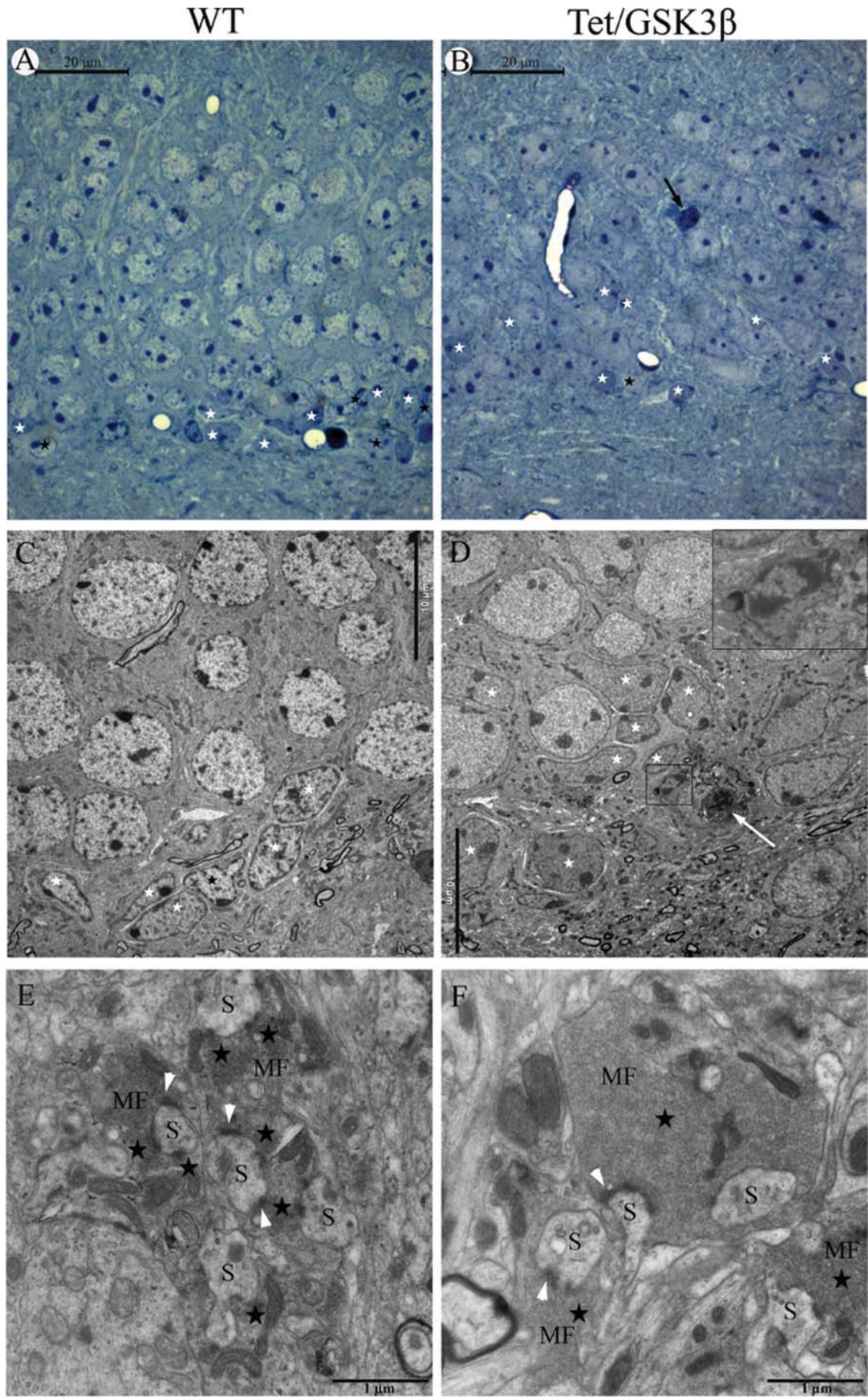

FIGURE 6. Impaired maturation in 1-month-old Tet/GSK3 $\beta$ mice. A, B: Semithin sections of the DG from 1-month-old wt and Tet/GSK3 $\beta$ stained with toluidine blue. The chromatin organization is altered in Tet/GSK3 $\beta$ mice, and there are differences in the organization and cell composition of the niches in the SGZ. In wt mice, the neurogenic niches form a homogeneous layer in the SGZ, whereas in Tet/GSK3 $\beta$ mice, the cells are dispersed in the GCL. Type D cells (white asterisks) are more abundant, and they are not only located in the SGZ but also in the GCL of Tet/ GSK3 $\beta$ mice. Type B cells are labeled with black asterisks, and the microglia are indicated by black arrows. C, D: Electron micrographs of niches in the SGZ. In addition to the differences in chromatin organization in wt samples (smooth chromatin characteristic of immature cells and clumped chromatin characteristic of mature cells), Type $B$ and Type $D$ cells are readily recognized in the SGZ. By contrast, the differences between these cells are not so marked in Tet/GSK3 $\beta$ mice, which make it difficult to distinguish them. This is due to the lack of differentiation (the differentiation in 1-month-old Tet/GSK3 $\beta$ mice resembles that observed in P6 wt mice). In Tet/GSK3 $\beta$ mice, pyknotic cells (white arrows) and microglia (enlarged image) are frequently observed. E: Electron micrograph of 1-month-old wt mossy fiber expansion synapse (MF) that contacts a pyramidal cell dendrite and that interacts with several dendritic spines (S) from CA3 proximal apical dendrites, emphasizing the relatively mature appearance of this complex at this stage. The terminals form numerous synaptic contacts (white arrowheads) with dendritic spines and clusters of vesicles (black asterisks) are located close to the contacts. By contrast, MFs have a smoother contour, and they interact with fewer dendritic spines in Tet/GSK3ß (F) mice. The vesicles are uniformly distributed along the cytoplasm. 

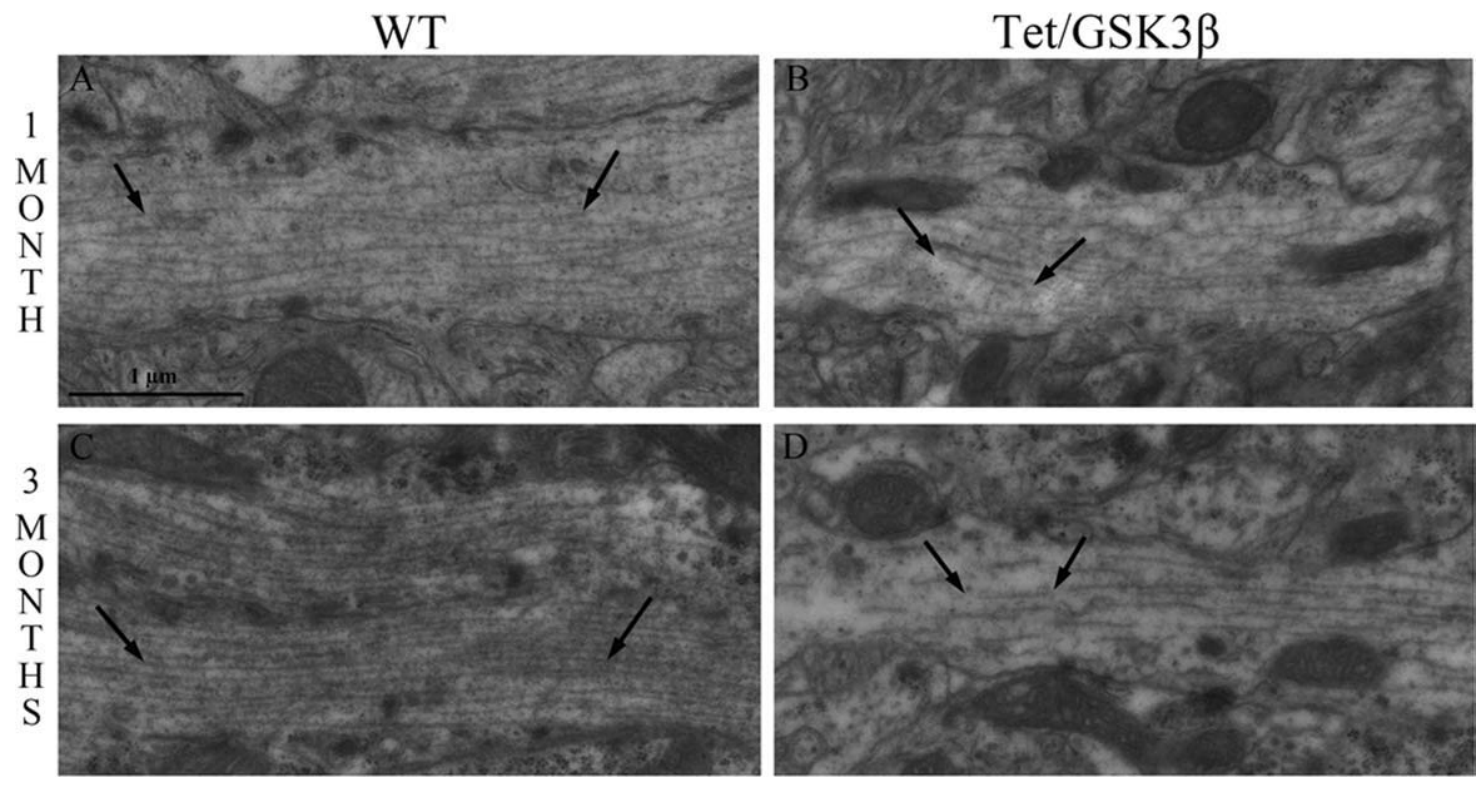

FIGURE 7. Microtubule disorganization. Electron micrographs of microtubules in the dendrites of granular neurons. In 1 (A) and 3-month-old (C) wt mice, microtubules are arranged longitudinally and parallel to one another, whereas in 1 (B) and 3-month-old (D) Tet/GSK3 $\beta$ mice, the microtubules appear to be disorganized.

MAP2, a heat-stable phosphoprotein predominantly expressed in the cell body and dendrites of neurons (Shafit-Zagardo and Kalcheva, 1998; Sanchez et al., 2000a) that is also a substrate for GSK3 $\beta$ (Sanchez et al., 2000b). Interestingly, there was a weaker MAP2 dendritic staining in Tet/GSK3 $\beta$ mice than in wt mice (Supporting Information Fig. 6).

\section{Microglia Activation}

Failed maturation and migration could induce neuronal death and degeneration, which would eventually activate microglia. Iba1 immunostaining showed an increase not only in the number of microglia but also in the size somata due to their activation in Tet/GSK3 $\beta$ mice compared to wt mice, confirming earlier observations (Fig. 8A). To study these changes in microglia, semithin toluidine-stained sections and EM ultrathin sections from 3 and 4-month-old mice were analyzed. In the semithin sections, microglia was characterized by their dark nucleus and the vacuoles (lysosomes) in their cytoplasm (Ibrahim et al., 1974). A increase not only in the somata size of the cell but also in the number of microglia was observed in Tet/ GSK3b mice. Interestingly, this abundant microglia was mainly located close to the niches in the SGZ and near degenerated neurons in the GCL. Hence, newborn cells appear to suffer a problem in maturation and/or migration, and they subsequently degenerate and are phagocyted. Moreover, we found that Tet/GSK3 $\beta$ microglia were more reactive than those in wt mice, given the number of lysosomes and heterogeneous bodies observed in their cytoplasm (Fig. 8B).

Microglia was quantified in semithin sections to assay the differences between Tet/GSK3 $\beta$ and wt mice. In 3-month-old
Tet/GSK3 $\beta$ mice, there was a 1.96-fold higher density of microglia than in wt mice (Fig. 8C). At 4 months, the increase in the density of microglia in Tet/GSK3 $\beta$ mice was 3.12-fold higher than in wt mice (Fig. 8C), suggesting an increase in reactive microglia over time. Interestingly, this increase in the microglia was correlated with the reduction in neurogenic niches (Fig. 8D). These results were in agreement with previous studies in which neuronal death was confirmed by TUNEL/ cleaved caspase-3 staining, and the presence of reactive glia and astrocytosis was reported (Lucas et al., 2001).

\section{DISCUSSION}

We have raised a conditional transgenic mouse that overexpresses GSK3 $\beta$ in the forebrain, and we have characterized some of the pathological effects of this altered expression (Lucas et al., 2001). These GSK3 $\beta$ transgenic mice have a smaller DG (Engel et al., 2006), which could be due to a failure in cell proliferation and maturation/migration that eventually produces premature neuron death. Also, they show an impaired memory (Hernandez et al., 2002).

Our results indicate that GSK3 $\beta$ overexpression provokes a block in cell maturation, which may be due to distinct effects. On one hand, immature neurons at different stages of maturation with excess GSK3 $\beta$ activity may experience modifications of some substrates of this kinase, like tau or MAP2 (Sanchez et al., 2000a; Lucas et al., 2001; de Barreda et al., 2010), 
A)
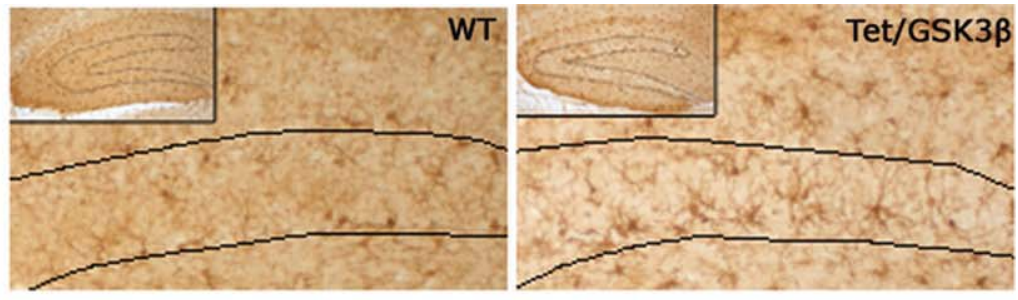

B)
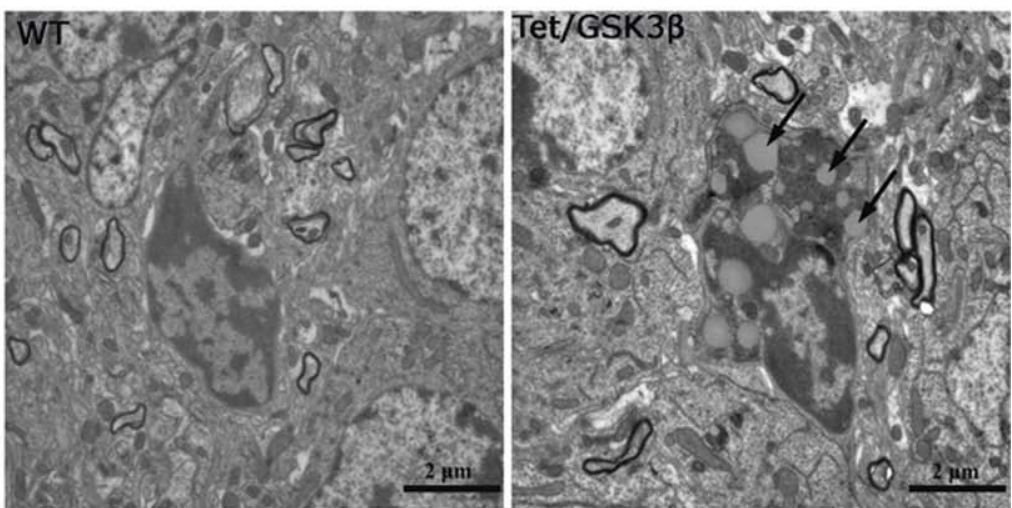

C)
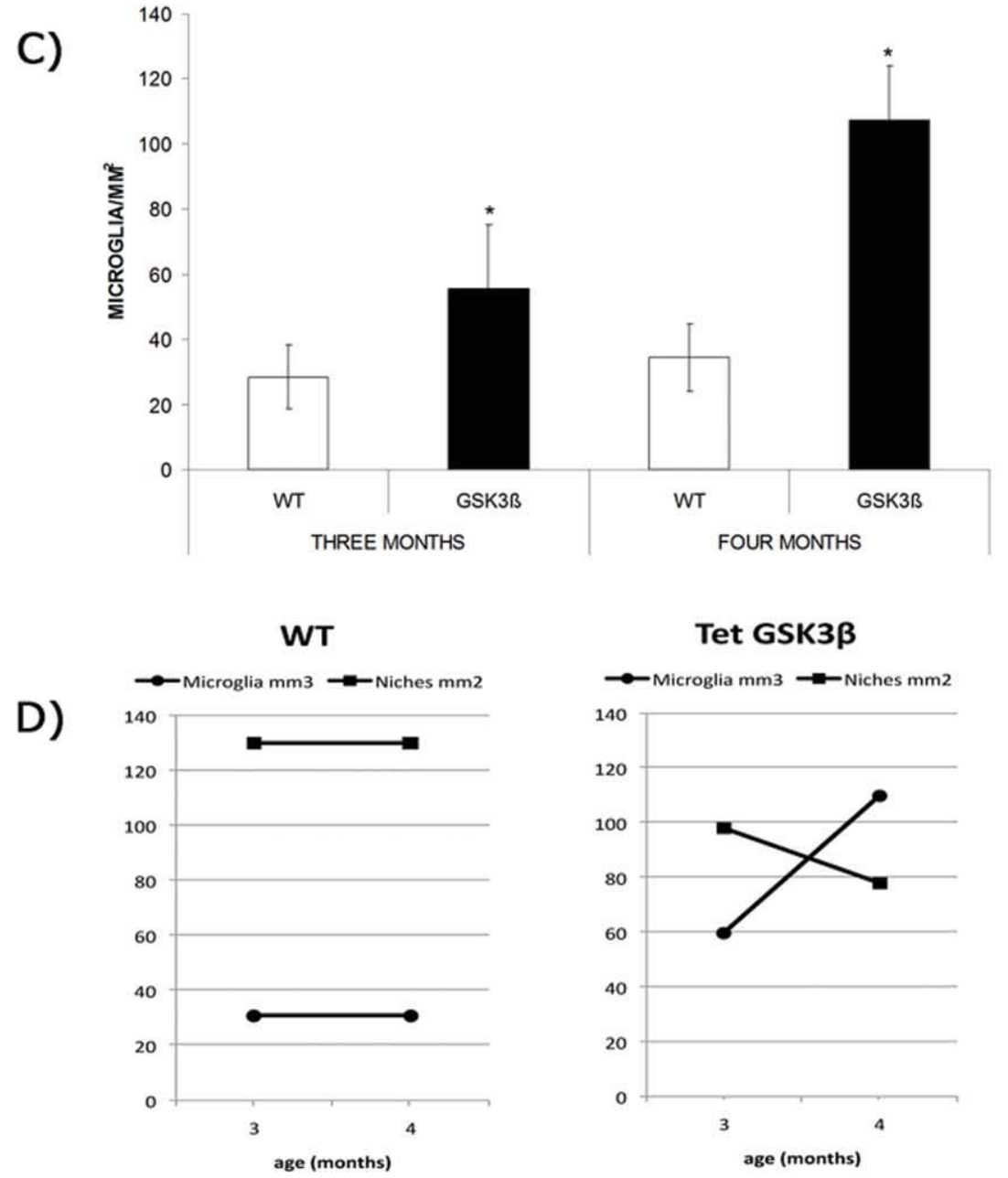

FIGURE 8. Increase Iba-1 immunostained and reactive microglia. A: DG immunostaining for microglia (Iba-1) in 3-month-old wt and GSK3 $\beta$ mice. B: Electron micrographs of microglia in wt and Tet/GSK3 $\beta$ mice. In GSK3 $\beta$ mice, microglia appear to be more reactive due to the abundance of lysosomes and expansions.

C: Quantification of Iba1 labeling in semithin sections of 3 and 4month-old mice indicating an increase in microglia over time. D: Correlation between the decrease in neurogenic niches and the increase in microglia.

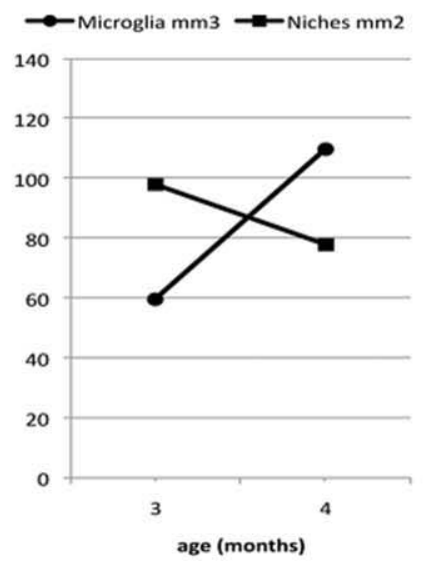




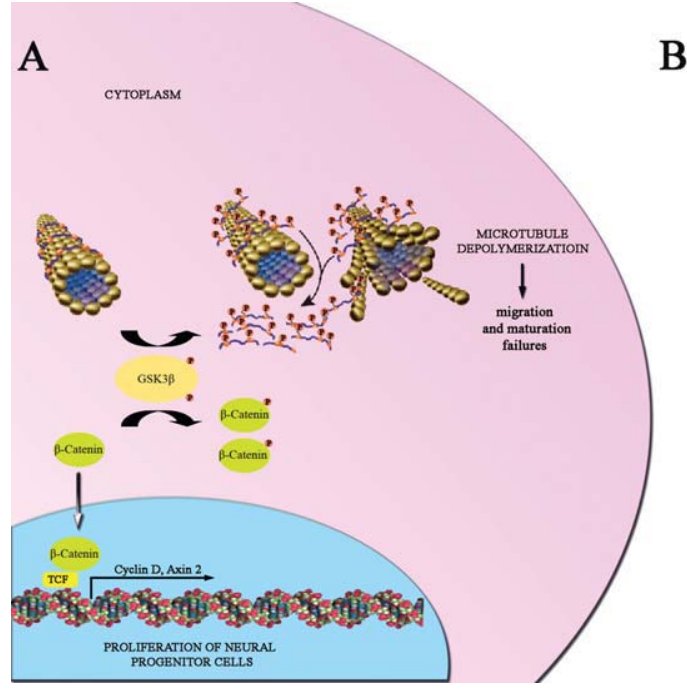

FIGURE 9. A working model of the neurogenic changes due to GSK3 $\beta$ overexpression. A: Scheme of the proposed role of GSK3 $\beta$ in the SGZ. This scheme presents a molecular mechanism by which the activation of GSK3 $\beta$ on one hand could produce premature exit from the cell cycle and the differentiation of neural precursor cells (NPCs), and on the other hand, a block in maturation. B: GSK3 $\beta$ may be overexpressed in $A D$ in a similar way as in our transgenic model. Hence, NPCs could overexpress GSK3 $\beta$ (or GSK3 $\beta$ could be activated), provoking exit from cell cycle, reducing the NPC population and inducing premature differentiation.

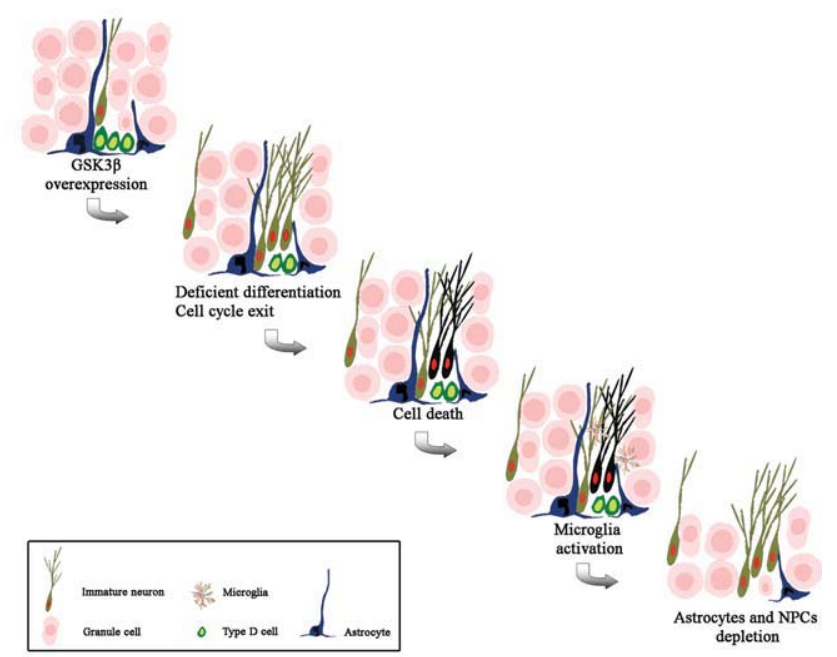

These cells and the cells at different stages of maturation will overexpress GSK3 $\beta$, producing defects in maturation and migration. All these phenomena lead to premature neuronal death in some cases, which will activate microglia. Astrocytes continue to divide to replenish the NPC population and generate fully mature granular neurons. The newly generated cells will suffer from the aforementioned problems and the cycle will start again. This repeated cycle could result in the long-term depletion of astrocytes and NPCs and the ensuing decrease in DG size. [Color figure can be viewed in the online issue, which is available at wileyonlinelibrary.com.] impairing their morphological differentiation and migration. The failure in migration could be due to microtubule disorganization and the interference in maturation. The failure in maturation is patent in 1 -month-old GSK3 $\beta$ mice in which no fully mature neurons are observed by EM, as well as in 3month-old GSK3 $\beta$ mice where the mossy fibers and synaptic boutons do not develop properly. On the other hand, neuronal progenitor cells may prematurely exit the cell cycle, prompting premature cell differentiation. This would lead to an accumulation of immature cells, whereas astrocytes/Type B cells still divide to produce new neuronal progenitors. In this scenario, the astrocyte population may be exhausted due to the continuous proliferation undertaken to replenish neural stem progenitor cell populations, which would explain the reduction in the number of astrocytes and neurogenic niches.

Why neural precursor cells (NPCs) prematurely exit the cell cycle is still not clear. It is possible that more undifferentiated type D cells start overexpressing GSK3 $\beta$ and promote cell-cycle exit through $\beta$-catenin signaling. However, we have no evidence that those proliferating cells, which should be mainly present in the SGZ, express GSK3 $\beta$ in our transgenic model. Alternatively, defects in maturation and neurodegeneration could activate GSK3 $\beta$ in NPCs, or GSK3 $\beta$ may be indirectly involved in cell proliferation.

FAD is a memory disorder that is provoked by mutations in three genes. One of these encodes the amyloid precursor protein (APP: Goate et al., 1991), which becomes more susceptible to cleavage by $\beta$ and $\gamma$ secretases when mutated, yielding the $A \beta$ peptide. This $A \beta$ peptide inhibits signal transduction cascades common to the insulin receptor or Wnt pathways, in both cases, resulting in an increase of GSK3 $\beta$ activity (Busciglio et al., 1995; Ferreira et al., 1997; Takashima et al., 1998; Townsend et al., 2007; Magdesian et al., 2008). The other two genes susceptible to mutation are those encoding presenilin 1 and presenilin 2 (PS-1 and PS-2), the mutation of which may also increase GSK3 $\beta$ activity (Levy-Lahad et al., 1995; Rogaev et al., 1995; Sherrington et al., 1995; Duff et al., 1996; Takashima et al., 1996; Price and Sisodia, 1998; Baki et al., 2004; Kimura et al., 2007). Thus, the effects of the presence of mutated APP, PS-1, or PS-2 on neurons converge at the activation of GSK3 $\beta$. Hence, our present working hypothesis is that the mutations in APP, PS- 1 , or PS- 2 that provoke FAD promote GSK3 $\beta$ activation. This activation of GSK3 $\beta$ could deregulate certain mechanisms implicated in proliferation, differentiation, migration, and neuronal cell death. Indeed, loss of DISC-1 function was recently shown to produce GSK3 activation and, as a consequence, a failure in cell proliferation and death (Mao et al., 2009). Because it modifies $\beta$-catenin activity, GSK3 $\beta$ is a kinase implicated in insulin-mediated signal transduction and in Wnt signaling (Barth et al., 1997). Interrupting $\beta$-catenin signaling reduces neural progenitor proliferation and neurogenesis in $\mathrm{AD}$ by promoting the premature exit from the cell cycle and blocking maturation (Adachi et al., 2007; Duan et al., 2007; He and Shen, 2009; Mao et al., 2009).

In this study, we propose the following working model to explain the possible mechanisms affected by GSK3 $\beta$ overex- 
pression (Fig. 9). GSK3 $\beta$ has two main effects, the first influences cell-cycle exit and premature differentiation, while the second blocks migration/maturation. Both these effects result in apoptosis and cell death. Although these processes occur, Type B cells/astrocytes still divide under the influence of microglia activation and also in response to the need to replenish the neuronal progenitor pool in the SGZ. Continuous astrocyte proliferation leads to the depletion of astrocytes and the neurogenic niche (Battista et al., 2006; Choi et al., 2008a,b). This cell death together with impaired neurogenesis produces a decrease in the volume of the DG, possibly recapitulating the events that occur in $\mathrm{AD}$ in humans. Thus, a potential therapy to redress these processes in $\mathrm{AD}$ pathology could involve the use of compounds to decrease GSK3 $\beta$ activity at early stages of the disease. However, at later stages, it may be advisable to use combined therapy by administering GSK3 $\beta$ antagonists and replacing depleted NPCs. Curiously, neuronal stem-cell transplantation improved memory, in a recent study, where neuronal precursor depletion was induced (Yamasaki et al., 2007).

\section{Acknowledgments}

The confocal microscopy was carried out by the Confocal Microscopy Service at the Centro de Investigación Principe Felipe (Valencia, Spain). We thank M. Soriano for his expert technical assistance with the EM. We also thank I. Borreda, M.L. Lop, P. Carrión, and E. Langa for their skilful technical support, M. Rabena for her kind help in the statistical analysis of the foci, Dr. C. Avendaño for his inestimable help with stereological analysis, and Dr. Ulises Gomez Pinedo for assistance with the immunochemistry.

\section{REFERENCES}

Adachi K, Mirzadeh Z, Sakaguchi M, Yamashita T, Nikolcheva T, Gotoh Y, Peltz G, Gong L, Kawase T, Alvarez-Buylla A, Okano H, Sawamoto K. 2007. $\beta$-Catenin signaling promotes proliferation of progenitor cells in the adult mouse subventricular zone. Stem Cells 25:2827-2836.

Aimone JB, Wiles J, Gage FH. 2006. Potential role for adult neurogenesis in the encoding of time in new memories. Nat Neurosci 9:723-727.

Amaral DG, Dent JA. 1981. Development of the mossy fibers of the dentate gyrus. I. A light and electron microscopic study of the mossy fibers and their expansions. J Comp Neurol 195:51-86.

Avila J. 2006. Tau phosphorylation and aggregation in Alzheimer's disease pathology. FEBS Lett 580:2922-2927.

Baki L, Shioi J, Wen P, Shao Z, Schwarzman A, Gama-Sosa M, Neve R, Robakis NK. 2004. PS1 activates PI3K thus inhibiting GSK-3 activity and tau overphosphorylation: Effects of FAD mutations. EMBO J 23:2586-2596.

Barth AI, Nathke IS, Nelson WJ. 1997. Cadherins, catenins and APC protein: Interplay between cytoskeletal complexes and signaling pathways. Curr Opin Cell Biol 9:683-690.

Battista D, Ferrari CC, Gage FH, Pitossi FJ. 2006. Neurogenic niche modulation by activated microglia: Transforming growth factor beta increases neurogenesis in the adult dentate gyrus. Eur J Neurosci 23:83-93.
Busciglio J, Lorenzo A, Yeh J, Yankner BA. 1995. beta-amyloid fibrils induce tau phosphorylation and loss of microtubule binding. Neuron 14:879-888.

Choi SH, Veeraraghavalu K, Lazarov O, Marler S, Ransohoff RM, Ramirez JM, Sisodia SS. 2008a. Non-cell-autonomous effects of presenilin 1 variants on enrichment-mediated hippocampal progenitor cell proliferation and differentiation. Neuron 59:568-80.

Choi YS, Cho HY, Hoyt KR, Naegele JR, Obrietan K. 2008b. IGF-1 receptor-mediated ERK/MAPK signaling couples status epilepticus to progenitor cell proliferation in the subgranular layer of the dentate gyrus. Glia 56:791-800.

Chuang TT. Neurogenesis in mouse models of Alzheimer's disease. Biochim Biophys Acta (in press).

Danscher G, Fjerdingstad EJ, Fjerdingstad E, Fredens K. 1976. Heavy metal content in subdivisions of the rat hippocampus (zinc, lead and copper). Brain Res 112:442-446.

de Barreda EG, Perez M, Ramos PG, de Cristobal J, Martin-Maestro P, Moran A, Dawson HN, Vitek MP, Lucas JJ, Hernandez F, Avila J. 2010. Tau-knockout mice show reduced GSK3-induced hippocampal degeneration and learning deficits. Neurobiol Dis 37:622629.

De Ferrari GV, Papassotiropoulos A, Biechele T, Wavrant De-Vrieze F, Avila ME, Major MB, Myers A, Saez K, Henriquez JP, Zhao A, Wollmer MA, Nitsch RM, Hock C, Morris CM, Hardy J, Moon RT. 2007. Common genetic variation within the low-density lipoprotein receptor-related protein 6 and late-onset Alzheimer's disease. Proc Natl Acad Sci USA 104:9434-9439.

Doetsch F, Hen R. 2005. Young and excitable: The function of new neurons in the adult mammalian brain. Curr Opin Neurobiol 15:121-128.

Duan X, Chang JH, Ge S, Faulkner RL, Kim JY, Kitabatake Y, Liu $\mathrm{XB}$, Yang CH, Jordan JD, Ma DK, Liu CY, Ganesan S, Cheng HJ, Ming GL, Lu B, Song H. 2007. Disrupted-In-Schizophrenia 1 regulates integration of newly generated neurons in the adult brain. Cell 130:1146-1158.

Duff K, Eckman C, Zehr C, Yu X, Prada CM, Perez-tur J, Hutton M, Buee L, Harigaya Y, Yager D, Morgan D, Gordon MN, Holcomb L, Refolo L, Zenk B, Hardy J, Younkin S. 1996. Increased amyloid- $\beta 42(43)$ in brains of mice expressing mutant presenilin 1. Nature 383:710-713.

Encinas JM, Vaahtokari A, Enikolopov G. 2006. Fluoxetine targets early progenitor cells in the adult brain. Proc Natl Acad Sci USA 103:8233-8238.

Engel T, Goni-Oliver P, Gomez-Ramos P, Moran MA, Lucas JJ, Avila J, Hernandez F. 2008. Hippocampal neuronal subpopulations are differentially affected in double transgenic mice overexpressing frontotemporal dementia and parkinsonism linked to chromosome $17 \tau$ and glycogen synthase kinase-3 $\beta$. Neuroscience 157:772-780.

Engel T, Lucas JJ, Gomez-Ramos P, Moran MA, Avila J, Hernandez F. 2006. Cooexpression of FTDP-17 $\tau$ and GSK-3 $\beta$ in transgenic mice induce tau polymerization and neurodegeneration. Neurobiol Aging 27:1258-1268.

Ferreira A, Lu Q, Orecchio L, Kosik KS. 1997. Selective phosphorylation of adult tau isoforms in mature hippocampal neurons exposed to fibrillar A 3 . Mol Cell Neurosci 9:220-234.

Goate A, Chartier-Harlin MC, Mullan M, Brown J, Crawford F, Fidani L, Giuffra L, Haynes A, Irving N, James L, Mant R, Newton P, Rooke K, Roques P, Talbot C, Pericak-Vance M, Roses A, Williamson R, Rossor M, Owen M and Hardy J. 1991. Segregation of a missense mutation in the amyloid precursor protein gene with familial Alzheimer's disease. Nature 349:704-706.

He P, Shen Y. 2009. Interruption of $\beta$-catenin signaling reduces neurogenesis in Alzheimer's disease. J Neurosci 29:6545-6557.

Hernandez F, Borrell J, Guaza C, Avila J, Lucas JJ. 2002. Spatial learning deficit in transgenic mice that conditionally over-express GSK-3 $\beta$ in the brain but do not form tau filaments. J Neurochem 83:1529-1533. 
Ibrahim MZ, Khreis Y, Koshayan DS. 1974. The histochemical identification of microglia. J Neurol Sci 22:211-233.

Jin K, Minami M, Lan JQ, Mao XO, Batteur S, Simon RP, Greenberg DA. 2001. Neurogenesis in dentate subgranular zone and rostral subventricular zone after focal cerebral ischemia in the rat. Proc Natl Acad Sci USA 98:4710-4715.

Jin K, Peel AL, Mao XO, Xie L, Cottrell BA, Henshall DC, Greenberg DA. 2004. Increased hippocampal neurogenesis in Alzheimer's disease. Proc Natl Acad Sci USA 101:343-347.

Kempermann G, Kuhn HG, Gage FH. 1998. Experience-induced neurogenesis in the senescent dentate gyrus. J Neurosci 18:3206-3212.

Kempermann G, Gast D, Gage FH. 2002. Neuroplasticity in old age: Sustained fivefold induction of hippocampal neurogenesis by longterm environmental enrichment. Ann Neurol 52:135-143.

Kimura T, Yamashita S, Fukuda T, Park JM, Murayama M, Mizoroki T, Yoshiike Y, Sahara N, Takashima A. 2007. Hyperphosphorylated tau in parahippocampal cortex impairs place learning in aged mice expressing wild-type human tau. EMBO J 26:5143-5152.

Kuhn HG, Dickinson-Anson H, Gage FH. 1996. Neurogenesis in the dentate gyrus of the adult rat: Age-related decrease of neuronal progenitor proliferation. J Neurosci 16:2027-2033.

Lazarov O, Marr RA. Neurogenesis and Alzheimer's disease: At the crossroads. Exp Neurol (in press).

Levy-Lahad E, Wasco W, Poorkaj P, Romano DM, Oshima J, Pettingell WH, Yu CE, Jondro PD, Schmidt SD, Wang K, Crowley AC, Fu Y-H, Guenette SY, Galas D, Nemens E, Wijsman EM, Bird TD, Schellenberg GD, Tanzi RE. 1995. Candidate gene for the chromosome 1 familial Alzheimer's disease locus. Science 269:973977.

Li B, Yamamori H, Tatebayashi Y, Shafit-Zagardo B, Tanimukai H, Chen S, Iqbal K, Grundke-Iqbal I. 2008. Failure of neuronal maturation in Alzheimer disease dentate gyrus. J Neuropathol Exp Neurol 67:78-84.

Lucas JJ, Hernandez F, Gomez-Ramos P, Moran MA, Hen R, Avila J. 2001. Decreased nuclear $\beta$-catenin, tau hyperphosphorylation and neurodegeneration in GSK-3 $\beta$ conditional transgenic mice. EMBO J 20:27-39.

Magdesian MH, Carvalho MM, Mendes FA, Saraiva LM, Juliano MA, Juliano L, Garcia-Abreu J, Ferreira ST. 2008. Amyloid- $\beta$ binds to the extracellular cysteine-rich domain of frizzled and inhibits Wnt/ $\beta$-catenin signaling. J Biol Chem 283:9359-9368.

Mao Y, Ge X, Frank CL, Madison JM, Koehler AN, Doud MK, Tassa C, Berry EM, Soda T, Singh KK, Biechele T, Petryshen TL, Moon RT, Haggarty SJ, Tsai LH. 2009. Disrupted in schizophrenia 1 regulates neuronal progenitor proliferation via modulation of GSK3 $\beta$ / $\beta$-catenin signaling. Cell 136:1017-1031.

Price DL, Sisodia SS. 1998. Mutant genes in familial Alzheimer's disease and transgenic models. Annu Rev Neurosci 21:479-505.

Rogaev EI, Sherrington R, Rogaeva EA, Levesque G, Ikeda M, Liang Y, Chi H, Lin C, Holman K, Tsuda T, Mar L, Sorbi S, Nacmias B, Piacentini S, Amaducci L, Chumakov I, Cohen D, Lannfelt L, Fraser PE, Rommens JM, George-Hyslop ST. 1995. Familial Alzheimer's disease in kindreds with missense mutations in a gene on chromosome 1 related to the Alzheimer's disease type 3 gene. Nature 376:775-778.
Sanchez C, Diaz-Nido J, Avila J. 2000a. Phosphorylation of microtubule-associated protein 2 (MAP2) and its relevance for the regulation of the neuronal cytoskeleton function. Prog Neurobiol 61:133-168.

Sanchez C, Perez M, Avila J. 2000b. GSK3 $\beta$-mediated phosphorylation of the microtubule-associated protein 2C (MAP2C) prevents microtubule bundling. Eur J Cell Biol 79:252-260.

Schaffer BA, Bertram L, Miller BL, Mullin K, Weintraub S, Johnson $\mathrm{N}$, Bigio EH, Mesulam M, Wiedau-Pazos M, Jackson GR, Cummings JL, Cantor RM, Levey AI, Tanzi RE, Geschwind DH. 2008. Association of GSK3B with Alzheimer disease and frontotemporal dementia. Arch Neurol 65:1368-1374.

Seki T, Arai Y. 1995. Age-related production of new granule cells in the adult dentate gyrus. Neuroreport 6:2479-2482.

Seri B, Garcia-Verdugo JM, Collado-Morente L, McEwen BS, Alvarez-Buylla A. 2004. Cell types, lineage, and architecture of the germinal zone in the adult dentate gyrus. J Comp Neurol 478:359-378.

Shafit-Zagardo B, Kalcheva N. 1998. Making sense of the multiple MAP-2 transcripts and their role in the neuron. Mol Neurobiol 16:149-162.

Sherrington R, Rogaev EI, Liang Y, Rogaeva EA, Levesque G, Ikeda M, Chi H, Lin C, Li G, Holman K, Tsuda T, Mar L, Foncin JF, Bruni AC, Montesi MP, Sorbi S, Rainero I, Pinessi L, Nee L, Chumakov I, Pollen D, Brookes A, Sanseau P, Polinsky RJ, Wasco W, Dasilva HAR, Haines JL, Pericak-Vance MA Tanzi RE, Roses AD, Fraser PE, Rommens JM and George-Hyslop ST. 1995. Cloning of a gene bearing missense mutations in early-onset familial Alzheimer's disease. Nature 375:754-760.

Takashima A, Noguchi K, Michel G, Mercken M, Hoshi M, Ishiguro K, Imahori K. 1996. Exposure of rat hippocampal neurons to amyloid $\beta$ peptide $(25-35)$ induces the inactivation of phosphatidyl inositol-3 kinase and the activation of tau protein kinase I/glycogen synthase kinase-3 $\beta$. Neurosci Lett 203:33-36.

Takashima A, Murayama M, Murayama O, Kohno T, Honda T, Yasutake K, Nihonmatsu N, Mercken M, Yamaguchi H, Sugihara S, Wolozin B. 1998. Presenilin 1 associates with glycogen synthase kinase- $3 \beta$ and its substrate tau. Proc Natl Acad Sci USA 95:96379641.

Townsend M, Mehta T, Selkoe DJ. 2007. Soluble A $\beta$ inhibits specific signal transduction cascades common to the insulin receptor pathway. J Biol Chem 282:33305-33312.

Tropepe V, Craig CG, Morshead CM, van der Kooy D. 1997. Transforming growth factor- $\alpha$ null and senescent mice show decreased neural progenitor cell proliferation in the forebrain subependyma. J Neurosci 17:7850-7859.

Yamasaki TR, Blurton-Jones M, Morrissette DA, Kitazawa M, Oddo S, LaFerla FM. 2007. Neural stem cells improve memory in an inducible mouse model of neuronal loss. J Neurosci 27:1192511933.

Zhao C, Teng EM, Summers RG Jr, Ming GL, Gage FH. 2006. Distinct morphological stages of dentate granule neuron maturation in the adult mouse hippocampus. J Neurosci 26:3-11.

Zhao C, Deng W, Gage FH. 2008. Mechanisms and functional implications of adult neurogenesis. Cell 132:645-660. 